\title{
Safety Performance in Air Traffic Controller (ATC) Bali Indonesia
}

\author{
Lalu Muhammad Saleh ${ }^{1}$, Muhammad Rachmat ${ }^{2}$ \\ $\left\{\right.$ ms_lalu79@yahoo.com ${ }^{1}$, rahmat.muh@gmail.com $\left.{ }^{2}\right\}$ \\ Occupational Health and Safety Departement, Faculty of Public Health Hasanuddin University ${ }^{1}$ \\ Promotion Health Departement, Faculty of Public Health Hasanuddin University ${ }^{2}$
}

\begin{abstract}
Safety performance on Air Traffic Controller (ATC) worker is for keeping the ATC worker healthy and safe so that they can work optimally. This study aimed to analyze the correlation between sex, age, work time, license, and rating on the safety performance of ATC worker. This study was a cross-sectional study with the total of the samples were 30 respondents at Airnav Ngurah Rai, Bali-Indonesia. The data analysis utilized Chi-Square. The result of the study showed that the highest safety performance was sufficient safety performance with the percentage of $36,7 \%$ and the lowest one was the excellent safety performance with a percentage of $10 \%$. Significant variable with safety performance was years of services on safety performance with $\mathrm{P}$ value $=0,041$. Meanwhile, insignificant variables were sex, age, license, and rating on safety performance. Moreover, the conclusion of this study was years of service correlated significantly with safety performance, weather, sex, age, license, and the rating did not correlate significantly.
\end{abstract}

Keywords: Safety performance, sex, age, work time, license, rating

\section{Introduction}

Heinrich (1931) in Raouf (2011) every accident must have a trigger and the axiom that $88 \%$ of accidents caused by human factors with unsafe actions. For example, case of a plane accident is more occurred not only because of pilot's fault but also because of bad weather, terrorist attacks, sabotage, communication fault with control tower which is ATC worker, even because the plane condition is unworthy operation [1].

Various reports have found that the number of aircraft accidents occurring in some countries is still relatively high, according to Jenamani and Kumar, (2013) during 2000 to 2012, two major aircraft accidents occurred in India. Alliance Air Flight CD-7412 'crashed at Patna airport which killed about 60 passengers and Air India Express Flight 812' crashed at Mangalore airport, killing 158 passengers [2]. However, according to Jenamani and Kumar, there is still the possibility of several other aircraft accidents from the category of flights that are not scheduled to occur in India. In Japan, from 1974 to 2010 there were 467 reported plane crashes, the number of accidents involving small aircraft that is 351 or $75.1 \%$ of the number of aircraft accidents during that period [3]. In Indonesia, flight accident investigation data from 2010 to 2016 varies each year, with the number of accidents and incidents of 82 and 130 cases, each with a death toll of 375 and 144 injured respectively. Factors causing accidents in 
Indonesia are highest related to human factor that is $67.12 \%$, and the lowest related facility is $4.79 \%$. And technical and environmental factors, respectively $15.75 \%$ and $12.33 \%$ [4].

Recently, up to mid-2017 there were plane crashes in Papua - Indonesia with 6 accidents and 7 serious incidents, according to the director of DKPPU, factors contributing to the incident were the discipline and visual flight visual regulation procedure (VFR), the approach procedure (unstabilize approach), and aircraft performance (load, weight \& balance, and aircraft performance at altitude), pilot qualification, application of SMS (Safety Management System), compliance to relief aspects, airport infrastructure and weather [5].

The International Air Transport Association (IATA) also reported the safety performance of the commercial aviation industry in 2016 that all crash rates measured in accidents per 1 million flights increased from 1.61 to 1.79 by 2015 . In 2011-2015 there were about 13 , 4 fatal accidents. And 371 deaths per year [6].

The results Pape, Wiegmann, and Shappell, (2001), show that accidents and incidents related to the role of ATC as an air traffic guide are rare. However, when these events occur, it is likely to involve local controllers interacting with multiple aircraft in the air under VFR sunlight conditions [7]. In recent decades, human error has increased as part of the phenomenon of the system, where human error is seen caused by hidden conditions in the system in which human transport operators work. Therefore, to avoid future accidents, we should be able to consider the quality of all systems, especially operators, to avoid human error capable of causing accidents [8].

However, the fault on ATC worker can occur because work performance decreases as the consequence of unhealthy work condition. Hence, it can cause a plane accident. Furthermore, the safety performance is needed in order to make ATC workerscan work optimally in controlling plane. The small error in the work of ATC workers can cause fatal result such as a plane accident.

\section{Data and Method}

\subsection{Location of Study}

This study was conducted at AirNav Indonesia, a branch office of Ngurah Rai-Bali, Indonesia, in September 2014.

\subsection{Design and Variable of Study}

This research is a quantitative study with cross sectional study method or more specifically expressed as survey study or observation study, according to Timmreck, (2014) cross sectional study is a study where researchers want to see changes in one research characteristic compared and reviewed about other characteristic changes. In this study intended to analyze the correlation between sex, age, years of service, license, and rating on the safety performance of ATC [9].

\subsection{Population and Sample}

Population in this study was all of ATC workers at Airnav Ngurah Rai, Bali. The procedure for collecting the sample was in random sampling with sample selection, which all of the 
population members had a similar chance to be chosen [10]. The sample of this study was the chosen ATC workers, which were 30 respondents.

\subsection{Data Collection}

Data collection was conducted by using a questionnaire of safety performance that had been conducted validity and reliability test and by using an observation sheet. Implementation of validity and reliability test solely to maintain the accuracy of research in observing, measuring, interviewing, interpreting, reviewing, digging information derived from research subjects with the correct questionnaire as suggested [11].

\subsection{Data Analysis}

Data has been collected and then processed based on predetermined criteria, then processed using univariate analysis, which aims to describe the distribution of research variables that is by presenting the value of data variation. This variable is addressability performance, gender, age, service period, license, and rating. And bivariate analysis to see the relationship between sex variables, age, employment, licensing, and ATC safety performance assessment, said to be significant if the value of $\mathrm{p}<0.05$.

\section{Results}

Table 1. Safety Performance in Air Traffic Controller (AT) Ngurah Rai Bali

\begin{tabular}{ccc}
\hline Safety Performance & Frequency & Percentage \\
\hline Low & 7 & 23,3 \\
Middle & 11 & 36,7 \\
Hight & 9 & 30,0 \\
Highest & 3 & 10,0 \\
Total & 30 & 100,0 \\
\hline
\end{tabular}

Table 2. Sex and Safety Performance in ATC Ngurah Rai Bali Indonesia

\begin{tabular}{|c|c|c|c|c|c|c|}
\hline \multirow[t]{2}{*}{ Sex } & \multicolumn{4}{|c|}{ Safety Performance } & \multirow[t]{2}{*}{ Total } & \multirow[t]{2}{*}{ Chi-Square } \\
\hline & Low & Middle & High & Highest & & \\
\hline Man & 4 & 8 & 7 & 2 & 21 & $P$ \\
\hline Woman & 3 & 3 & 2 & 1 & 9 & $=0,834$ \\
\hline Total & 7 & 11 & 9 & 3 & 30 & \\
\hline
\end{tabular}

Table 3. Age and Safety Performance in ATC Ngurah Rai Bali Indonesia.

\begin{tabular}{|c|c|c|c|c|c|c|}
\hline \multirow{2}{*}{$\begin{array}{l}\text { Age } \\
\text { (Years) }\end{array}$} & \multicolumn{4}{|c|}{ Safety Performance } & \multirow[t]{2}{*}{ Total } & \multirow{2}{*}{$\begin{array}{l}\text { Chi- } \\
\text { Square }\end{array}$} \\
\hline & Low & Middle & High & Highest & & \\
\hline$<23$ & 1 & 4 & 2 & 0 & 7 & \\
\hline $23-35$ & 1 & 2 & 3 & 2 & 8 & \\
\hline $36-38$ & 1 & 3 & 3 & 1 & 8 & $\mathrm{P}=0,364$ \\
\hline $39-51$ & 4 & 2 & 1 & 0 & 7 & \\
\hline
\end{tabular}




\begin{tabular}{|c|c|c|c|c|c|c|}
\hline \multirow{2}{*}{$\begin{array}{l}\text { Years of } \\
\text { Service } \\
\text { (Years) }\end{array}$} & \multicolumn{4}{|c|}{ Safety Performance } & \multirow[t]{2}{*}{ Total } & \multirow{2}{*}{$\begin{array}{c}\text { Chi- } \\
\text { Square }\end{array}$} \\
\hline & Low & Middle & High & Highest & & \\
\hline$<2$ & 2 & 5 & 3 & 0 & 7 & \multirow{5}{*}{$\mathrm{P}=0,041$} \\
\hline $2-14$ & 1 & 0 & 2 & 2 & 8 & \\
\hline $15-17$ & 0 & 5 & 3 & 1 & 8 & \\
\hline$>17$ & 4 & 1 & 1 & 0 & 7 & \\
\hline Total & 7 & 11 & 9 & 3 & 30 & \\
\hline
\end{tabular}

Table 5. License and Safety Performance in ATC Ngurah Rai Bali Indonesia.

\begin{tabular}{cccccccc}
\hline Licence & & \multicolumn{2}{c}{ Safety Performance } & & & Total & $\begin{array}{c}\text { Chi- } \\
\text { Square }\end{array}$ \\
& Low & Middle & High & Highest & & \\
\cline { 4 - 7 } & 6 & 10 & 9 & 3 & 28 & $P$ \\
Senior & 1 & 1 & 0 & 0 & 2 & \\
ATC & & 11 & 9 & 3 & 30 & \\
Junior ATC & 7 & & & & & \\
Total & & & &
\end{tabular}

Table 6. Rating and Safety Performance in ATC Ngurah Rai Bali Indonesia.

\begin{tabular}{|c|c|c|c|c|c|c|}
\hline \multirow[t]{2}{*}{ Rating } & \multicolumn{4}{|c|}{ Safety Performance } & \multirow[t]{2}{*}{ Total } & \multirow{2}{*}{$\begin{array}{c}\text { Chi- } \\
\text { Square }\end{array}$} \\
\hline & Low & Middle & High & Highest & & \\
\hline APP & 5 & 4 & 5 & 3 & 17 & \multirow{3}{*}{$\begin{array}{c}P \\
=0,190\end{array}$} \\
\hline $\mathrm{ADC}$ & 2 & 7 & 4 & 0 & 13 & \\
\hline Total & 7 & 11 & 9 & 3 & 30 & \\
\hline
\end{tabular}

\section{Discussion}

\subsection{Safety Performance of ATC Workers}

ATC Safety performance is a healthy, comfortable, safe, and productive performance in work on ATC workers. Safety performance based on this study was conducted by obtaining data subjectively by using safety performance questionnaire that had been conducted validity and reliability test. Category of safety performance was obtained based on quartile result from the total of workers' answers toward some given questions. The result of this study showed that the safety performance on ATC workers showed sufficient safety performance as the most number of safety performance, which was in 11 workers $(36,7 \%)$ and the lowest one was having excellent safety performance that was in 3 workers $(10 \%)$. The further result was described in table 1. 
Furthermore, this study explained that safety performance, which was in the range of good and excellent safety performance $(40 \%)$ was lower than sufficient and low safety performance $(60 \%)$. This condition was occurred because working as ATC worker had a big petition in work so that safety flight could be guaranteed. Hence, the responsibility of the work needed high performance. In other word, ATC workers must not do any fault in their work.

According to this study and based on the explanation above, there something needed to be improved to increase safety performance level on ATC workers. The improvement for increasing safety performance on ATC workers at Ngurah Rai, Bali had to be conducted as soon as possible in order to avoid bad impact for flight because in the regulation of Indonesia ( $U U R I$ ) number 15, the year of 1992, regarding flight chapter 22 verse 1 explained that regarding the safety flight, an airplane that flew in area of Indonesia was given the service of flight navigation [12]. Based on this regulation, it was proved clearly that a navigator was assigned to guarantee the safety flight so that the passengers and crews were safe in the airplane, hence, the ATC workers' health had to be guaranteed and optimal in controlling airplane.

\subsection{Sex and Safety Performance}

Sex-based on this context was sex in authority (male and female). In table 2 explained the correlation between sex and safety performance. Based on table 2 above, it showed that the highest sex between male and female workers in safety performance was a male worker who had sufficient safety performance as many as 8 workers. Meanwhile, the lowest one was a female worker with excellent safety performance as many as 1 worker. This result showed that between male and female (sex) workers with safety performance did not correlate significantly with $P$ value $=0.835$.

Moreover, there was no significant correlation between sex and safety performance because there was no significant difference between male and female workers. All of their jobs, concerning either responsibility and carrier, were similar. ATC workers' job demanded high accuracy and concentration for both male and female worker. Besides, they also had a similar ability.

Women's groups are often classified as vulnerable groups in doing work Harrington and Gill, (2011) [13]. In many countries, distortions and discrimination in the labor market restrict the choice of women's work, the female labor force participation (FLFP) remains lower than male participation [14]. And According to Tarwaka and Sudiajeng, (2004) women generally only have physical strength $2 / 3$ of the physical ability or muscle strength of men, but in certain cases, women are more thorough than men. Also, women workers still have shares in their households and families [15]. Women's working days are longer than 4-6 hours compared to men (husband), even though women can still handle the work of the average man [13]. In the end, it can be concluded that no term that male worker was better in control rather than a female worker and vice versa, a female worker was better than the male one.

\subsection{Age and Safety Performance}

The older a person then the condition of memory and body will decrease the function that affects the performance of his work. But inevitably, in the young age group if asked to do things that are heavy or not by their capacity and see the maturity of thinking that is still not maximal, certainly work that may be different from the expected results. [16] Age based on 
this study was the workers' age since they were born until their birthday when this study was conducted. Table 3 explained the correlation between the age variable and safety performance variable. Based on the data above, it could be seen that the age of $39-51$ years old had the most number of low safety performance, which were 4 workers. This result did not show a significant correlation between age and safety performance with $\mathrm{P}$ value $=0,364$.

According to [17], With age, individuals will experience biological and psychological changes. Some of these changes may be better, and some are not. Older adults show significant disruption to tasks that require a focus of attention between the number of tasks and the level of complexity. They demonstrate the ability to perform tasks that require relevant selection; and although they are slower than younger adults, they do not experience a different disorder with a common disorder. They can still maintain concentration for long periods. The research conducted Chung J. Park, J. Cho, M. Park, Y. Kim, D. Yang, D. Yang, (2015) reveals that increased work skills in elderly workers do not correspond to an increase in the number of hours worked but with an increase cognitive ability [18].

Similarly, delivered by Beers and Butler, (2012), age does not necessarily hurt workplace performance [19]. This is particularly relevant if the ability is tailored to the requirements and work expertise to be taken into account. Such use of employee skill and experience strategies can be utilized for placement in the correct position so that age or decline in body functions cannot be attributed. Therefore, based on several studies the literature can support these variables age was not significant with safety performance pada ATC because young age and old age had been given similar responsibility, appropriate capacity, and they were required to be always healthy by the company for whenever they would do controlling. Either old workers or young workers had to be fit before working to always keep the safe flight.

\subsection{Years of Service and Safety Performance}

Years of service in this study was work time in a year on ATC workers who were as ATC. The result of Table 4 showed the correlation between work time and safety performance. The result of the study above explained that work time in less than 2 years, and 15-17 years had the most number of workers with a total of frequency was 5 workers for each with sufficient safety performance. This study resulted that there was a correlation between work time and safety performance with $\mathrm{P}$ value $=0,041$, which meant statistically, it was significant because $P$ value was under 0,05 . This situation explained that the longer the workers worked, the better the safety performance level. This occurred because the longer the workers worked, their experience would be more and more, which would affect their proficiency level. Besides, their quality and responsibility were better toward the jobs. This result is different from the previous year's findings by Bart B. Cobb, (1967) that the old ATC work period has no significant relationship with the performance [20]. These results are different because in the study, Bart B. Cobb, (1967) researchers emphasize age above 40 years with a relatively small sample size [20]. While in this study, although the sample was also relatively small, the researchers did not limit the age of sampling so that samples found at the site or by chance met with the researcher, could be sampled, and the subjects considered in accordance with the source data were declared as samples.

Explained that every time dimension would give stimulus on the direction, development, and change from the activity of workers' performance. The development and change of performance could be better and could be worse, depended on the work environment. Performance would be better if the work time were a long time with a supported work environment [21]. Hence, it would create optimal work. Nevertheless, if the work time were a 
long time with a bad work environment, it would cause low performance for the workers. Also, in the findings, Bushiri, (2014) states that the length of work related to the worker's performance is determined by the ability of the worker in performing his duties to include the willingness to do his best [22].

\subsection{License and Safety Performance}

Before providing Air Traffic Control services, the controller must have appropriate qualifications and licenses. They are required to hold an Air Traffic Control License (ATCO) which includes rating assessments and related assessments that are appropriate to the task. ATCO licenses are issued by the CAA upon completion of appropriate training courses, exams, and preliminary assessments.

The granting of licenses within a country is, of course, different depending on the policy of the State government. In Indonesia, the Civil Aviation Authority stipulates the provisions for friendship certificate for beginners or juniors in Law No. 1 of 2009 on Aviation, Decree of the Director General of Civil Aviation No. SKEP 172 / VII / 1997 Concerning the Certificate of Flight Flight Guides and Decisions of the Minister of Transport KM Number 12 the Year 2009 (PKPS 69) About License Requirements, Ratings, Training, and Skills for Air Traffic Guidance Personnel [24].

Based on the results of the study in table.5 showed that the most number of licenses between senior and junior one was senior ATC's license, who had sufficient safety performance with the frequency of 10 workers. This result showed that there was no correlation between license and safety performance with $\mathrm{P}$ value $=0,656$. The particular concern is the possibility of this analysis not having a significant relationship with performance because more senior ATC subjects were found during the survey than the junior athletes around $93.3 \%$. However, it should also be noted, the correlation between license and safety performance was insignificant because the problem of ATC worker's license was really good, which either senior ATC's license or junior ATC's license were schooled in order to have those licenses either in DII for junior ATC or DIII (diploma) for senior ATC. Besides, a renewal of the license was minimum conducted once in 2 years.

One of the most important reviews of the contents of the legislation is that the candidate of air traffic guides who has performed the theoretical exams, medical examinations, and medical examinations and graduated, are certified according to their application [25]. Then for the expired ATC license to extend by predetermined operating standards, the Procedures for Issuing and Extending the License of Junior Personnel and Senior Air Traffic Control (JATC and SATC) have been compiled in CASR 69. The certificate shall be issued no later than 14 working days after the applicant has passed the exam. With the provisions of this legislation, the controllers are expected to meet operational feasibility standards in guiding air traffic, so that safety performance is always optimal both senior and junior ATC.

\subsection{Correlation of Rating and Safety Performance}

To maintain the stability of safety and efficiency in the operation of air traffic guidance, ATCs are required to demonstrate or maintain or enhance their competence on an ongoing basis [25]. In Indonesia, competency assessments are conducted through a series of practical tests contained in SI 69 - 01 Guidance Materials and Procedures for Air Traffic Controller License and Ratings. Ratings are part of the Authorization related to the license and form part thereof, stating the special conditions, privileges, and restrictions relating to such licenses [26]. This study, which looked at the Approach Control Office (APP) and Aerodrome Control 
Tower (ADC) ratings shown in table 6 show that the highest rating was ADC rating with sufficient safety performance as many as 7 workers. The result above showed there was no significant correlation between rating and safety performance with $\mathrm{P}$ value $=0,190$. However, the rating was not significant with safety performance because the rating that was owned by ATC workers in Tower and Radar room had been conducted a tested minimum once in 6 months.

This study is different from the findings of the performance assessment carried out Turhan, (2009) on the turbo ATC unit, i.e. there are significant differences in Controlled Airspace with officer performance [27]. Approach control units produce the highest scores on performance statements related to performance compared to other units. The possibility of this study is not aligned because of the difference of instrument used, where Turhan, (2009) using perception performance questionnaire and in this study the researchers directly assess the performance of officers with questionnaires made by researchers but has been tested the validity and reliability, so that the instrument used in the field is worthy of being used on the subject the researcher wants to study. Hence, the rating problem tended to be noticed by the company toward all of the workers. This condition enabled to occur insignificant correlation between rating and safety performance.

In the end, the importance of a system quality improvement in the aviation sector, especially the air traffic controller division is still an important concern, so that the human factor positioned as the highest cause that can affect ATM and flight systems can be minimized again. According to Dumitru and Boscoianu, (2015) for a better understanding of human factors, a gradual approach needs to be done with the help of the "SHELL" theoretical model that can be adapted to the conditions in the ATC environment, as a general illustration of the causes of human factor linkage with performance, following [28].

1. Liveware is a core component of this model; all other components must be tailored to the center of the model, i.e., the human or the controller itself.

2. Liveware-Hardware, Is a component that is often considered when associated with manmachine: designing chairs depending on the characteristics of the human body, designing the display depending on the characteristics of sensory information processing, etc. In general, the emphasis is to apply ergonomics in the ATC work environment.

3. Liveware-software, This interface is about human and procedure, manual and checklists, symbologies, and computer software used during ATC work activities.

4. Liveware-environment, In this case, the environment around the ATC work plays an important role in the performance of ATC as must pay attention to the standard noise, lighting, temperature, humidity, mechanical vibration, layout, etc.

5. Liveware-Liveware, Points emphasize more about interpersonal relationships. Such as paying attention to leadership, teamwork between team members, teamwork, and interpersonal interaction. Also, the scope of this interface is like staff/management relationships, work climate, climatic organization, and organizational pressures that can affect human performance.

\section{Conclusion}

Conclusions this research are years of service significant correlation with safety performance in ATC Bali Indonesia and sex, age, rating, and license not significant correlation with safety performance for ATC Bali.

Acknowledgment. Thank you for General Manager Air Nav Branch Bali Indonesia and Air Traffic Controllers Bali Indonesia. 


\section{References}

[1] Raouf, A.: Theory of Accident Causes, International Labour Organization. http:// www. iloencyclopaedia.org/part-viii-12633/accident-prevention/92-56-accident-prevention/theory-ofaccident-causes (2011)

[2] Jenamani, R. K. and Kumar, A.: Bad weather and aircraft accidents - global Indian scenario. Current Science. Vol. 104, pp. 316-325. (2013)

[3] Iwadare, K. and Oyama, T.: Statistical Data Analyses on Aircraft Accidents in Japan: Occurrences, Causes and Countermeasures. American Journal of Operations Research. Vol. 5, pp. 222-245. (2015)

[4] KNKT.: Data Investigasi Kecelakaan Penerbangan. Indonesia. (2016)

[5] Nistanto, R. K.: Ini Penyebab Seringnya Kecelakaan Pesawat di Papua, Kompas.com. Available at: http://tekno.kompas.com/read/2017/09/20/14400007/ini-penyebab-seringnya-kecelakaan-pesawat-dipapua. (2017)

[6] International Air Transport Association.: IATA Releases 2016 Airline Safety Performance. (2017)

[7] Pape, A., Wiegmann, D. and Shappell, S.: Air traffic control (ATC) related accidents and incidents a human factors analysis. Presented at the 11th International Symposium on Aviation Psychology. Columbus, OH: The Ohio State University, Vol.1.pp. 1-4. (2001)

[8] Phillips, R. O.: What is fatigue and how does it affect the safety performance of human transport operators?.pp.1-124 (2014)

[9] Timmreck, T. C.: Epidemiologi. Jakarta. EGC.pp.1-45 (2014)

[10] Kuntoro.: Metode Sampling Dan Penentuan Besar Sampling. Surabaya. Pustaka Melati. (2010)

[11] Murti, B.: Prinsip dan Metode Riset Epidemiologi. Surakarta. Gadjah Mada

[12] Isnaeni, M.: Hipotek Pesawat Udara di Indonesia. Surabaya. CV. Dharma Muda. University Press. Pp.34-50 (1995)

[13] Harrington, J. M. and Gill, F. S.: Buku Saku Kesehatan Kerja. Jakarta. EGC.pp.317 (2011)

[14] Kochhar, K.: Women, Work, and the Economy. Macroeconomic Gains from Gender.pp.1-32 (2013)

[15] Tarwaka, S. H. A. and Sudiajeng, L.: Ergonomi untuk keselamatan, kesehatan kerja dan produktivitas. UNIBA, Surakarta. Pp.34-50(2004)

[16] Saleh, L. M.: K3 Penerbangan. Sebuah Kajian Keselamatan kerja pada Karyawan Air Traffic Controller (ATC). Yogyakarta: Deepublish.pp.17-30 (2017)

[17] Riddle, D. R. and Wake.: Brain Aging Models, Methods, And Mechanisms. London, New York. CRC Press. Pp.100-109 (2007)

[18] Chung J. Park, J. Cho, M. Park, Y. Kim, D. Yang, D. Yang, Y.: A study on the relationships between age, work, experience, cognition and work ability in older employees working in heavy industry. The society of physical therapy science. Vol. 27, pp. 155-157. (2015)

[19] Beers, H. and Butler, C.: Age related changes and safety critical work. dentification of tools and a review of the literature.pp. 88 (2012)

[20] Bart B. Cobb, M. S.: The Relationships Between Chronological Age, Length of Experience, and Job Performance Ratings of Air Route Traffic Control Specialists. U.S. pp. 2-9 (1967)

[21] Wang, S. and Noe, R. A.: Knowledge sharing. A review and directions for future research. Human Resource Management Review. Elsevier Inc. Vol. 20, pp. 115-131. (2010)

[22] Bushiri, C. P.: The Impact Of Working Environment On Employees. Performance The Case Of Institute Of Finance Management In Dar Es Salaam Region. University of Tanzania.pp. 1-88 (2014)

[23] CAA.: Air Traffic Controller Licence, Civil Aviation Authority.UK. Available at: https://www.caa.co.uk/Commercial-industry/Airspace/Air-traffic-control/Licences/Air-TrafficController-Licence/. (2016)

[24] Dephub.: Sertifikat Kecakapan Junior Air Traffic Controller (JATCJatc). Direktorat Jenderal Perhubungan Udara Kementerian Perhubungan Republik Indonesia (2009)

[25] ICAO.: International Civil Aviation Organization. Bangkok, Thailand (2015)

[26] Kemenhub RI.: Staff Instruction 69-01 Guidance Material and Procedures for Issuance Air Traffic Controller Licence and Ratings. Jakarta. (2009) 
[27] Turhan, U.: Performance Perception of Turkish Air Traffic Controllers. International Journal of Civil Aviation. Vol. 1, pp. 74-90. (2009)

[28] Dumitru, I. M. and Boscoianu, M.: Human Factors Contribution To Aviation Safety. International Conference of Scientific Paper. Vol. pp. 1-5. (2015) 